\title{
ROLE OF PLASMA N-TERMINAL PRO-BRAIN NATRIURETIC PEPTIDE (NT-PRO-BNP), A DIAGNOSTIC AND PROGNOSTIC BIOMARKER OF ACUTE DYSPNOEA OF CARDIAC DISEASES
}

\author{
Sarat Chandra Singh¹, Madhusmita Patnaik², Srikant Kumar Sahoo ${ }^{3}$, Gautam Patnaik ${ }^{4}$ \\ ${ }_{1}^{1}$ Assistant Professor, Department of General Medicine, SCB Medical College, Cuttack, Odisha. \\ ${ }^{2}$ Assistant Professor, Department of General Medicine, SCB Medical College, Cuttack, Odisha. \\ 3Junior Resident, Department of General Medicine, SCB Medical College, Cuttack, Odisha. \\ ${ }_{4}^{4}$ Research Associate, SCMM, JNU, Delhi.
}

\section{ABSTRACT}

\section{BACKGROUND}

Early detection and accurate diagnosis of heart failure remain a huge clinical challenge in patients with acute dyspnoea of various aetiologies. Different biomarkers of left ventricular dysfunction are being studied to differentiate acute cardiogenic from noncardiogenic dyspnoea. Amongst those, Brain Natriuretic Peptide (BNP) is an important biomarker for diagnosing acute stage of cardiac dyspnoea.

The aim of this study is to assess the Plasma N-Terminal Pro-Brain Natriuretic Peptide (NT-ProBNP) level in acute dyspnoea of various aetiologies and to establish the diagnostic or prognostic value of plasma NT-ProBNP in acute dyspnoea of cardiac diseases.

\section{MATERIALS AND METHODS}

In our study, we have taken 84 cases of acute dyspnoea. The acute dyspnoea above 15 years of age were included in the study. Whereas dyspnoea due to chest trauma, renal insufficiency (serum creatinine $>2.5 \mathrm{mg} / \mathrm{dL}$ ), previously known as valvular heart diseases and severe coronary ischaemia identified as > 0.1 MV ST-segment elevation or ST depression on 12-lead ECG were excluded from the study. After taking patient's history, the clinical examination with routine blood test, electrocardiography and chest x-ray were done. In addition, blood sample was collected for NT-ProBNP measurement.

\section{RESULTS}

In our study group, out of 84 cases Male= $55(65.4 \%)$ and Female= $29(34.6 \%)$. Among those cases $40(47.6 \%)$ had acute cardiac dyspnoea, whereas $44(52.4 \%)$ had non-cardiac dyspnoea. The mean \pm SD NT-ProBNP concentration of cases with acute cardiac dyspnoea was $(4539.7 \pm 4342.9 \mathrm{pg} / \mathrm{mL})$, which was significantly higher than the cases with non-cardiac dyspnoea $(136.6 \pm 94.7 \mathrm{pg} /$ $\mathrm{mL}),(\mathrm{P}<0.00001)$. On the evaluation of acute heart failure according to NYHA (New York Heart Association classification), 44 (52.4\%) had NYHA Class-I symptoms, 3 (7.5\%) had NYHA Class-II symptoms, 10 (25\%) had Class-III symptoms and 27 (67.5\%) had Class-IV symptoms that demonstrate the significant relationship of NT-ProBNP of NYHA symptom severity with analysis using ANOVA (P < 0.00001). The median NT-ProBNP level was $150 \mathrm{pg} / \mathrm{mL}$ (IQR- $713 \mathrm{pg} / \mathrm{mL}$ ) in patients with left ventricular ejection fraction (LVEF) $>50 \%$ and $4580 \mathrm{pg} / \mathrm{mL}$ (IQR- $3180 \mathrm{pg} / \mathrm{mL})$ in those with $\mathrm{LVEF}<50 \%(\mathrm{P}<0.00001)$.

\section{CONCLUSION}

The serum NT-ProBNP measurement is a useful parameter for diagnosing cardiac causes of dyspnoea and also acute heart failure as per NYHA class. It can be used for early detection and management of acute heart failure.

\section{KEYWORDS}

Plasma N-Terminal Pro-Brain Natriuretic Peptide, Acute Dyspnoea, Coronary Ischaemia, Valvular Heart Disease.

HOW TO CITE THIS ARTICLE: Singh SC, Patnaik M, Sahoo SK, et al. Role of plasma N-terminal pro-brain natriuretic peptide (NTPRO-BNP), a diagnostic and prognostic biomarker of acute dyspnoea of cardiac diseases. J. Evolution Med. Dent. Sci. 2017;6(95): 7030-7035, DOI: $10.14260 /$ jemds/2017/1525

\section{BACKGROUND}

Early detection and accurate diagnosis of heart failure remain a huge clinical challenge in patients with acute dyspnoea. Though ECG and chest $x$-ray merely serves as baseline investigations, the diagnosis is eventually only confirmed by a 2D-echocardiogram coupled with Doppler flow study.

'Financial or Other Competing Interest': None.

Submission 22-11-2017, Peer Review 13-12-2017,

Acceptance 15-12-2017, Published 23-12-2017.

Corresponding Author:

Dr. Madhusmita Patnaik,

Assistant Professor,

$P G$ Department of Medicine,

SCB Medical College, Cuttack, Odisha, India.

E-mail:dr.madhusmita.med@gmail.com

DOI: $10.14260 /$ jemds/2017/1525

\section{(c) (i) $\$$}

Biomarkers of left ventricular dysfunction are being studied to differentiate cardiogenic from non-cardiogenic dyspnoea. Brain Natriuretic Peptide (BNP) is a leading bookmaker.(1) The BNP is a group of Natriuretic peptides that are involved in the regulation of diuresis, which antagonises the vasoconstrictor effects of the renin-angiotensinaldosterone system (RAAS).(1) BNP is produced by myocytes in response to increased left ventricular wall stretch.(2) It is derived from an intracellular 108 amino acid precursor protein, which is cleaved into 2 fragments and released by myocytes yielding N-Terminal Pro-Brain Natriuretic Peptide (NT-ProBNP), i.e. 1-76 amino acids inactive form and BNP i.e. 77-108 amino acids active form..$^{(1,2,3)}$ A close correlation exists between these peptide levels. However, in patients with left ventricular dysfunction, the proportional and absolute increase of NT-ProBNP exceeds that of BNP.(4)

NT-ProBNP has longer half-life (approximately $60-120$ mins) than BNP (approximately 20 mins), which increases 
specimen stability and more robust results. Patient presented with acute dyspnoea, may be due to cardiovascular causes like Congestive Heart Failure and Acute Coronary Syndrome or respiratory causes like Chronic Obstructive Pulmonary Disease, Bronchial Asthma, Acute Bronchitis, Pneumonia or mixed (Cardio-Respiratory causes) or other causes like anxiety, fever, sepsis etc. Diagnostic uncertainty in patients with complaints of acute shortness of breath presenting to the hospital may cause the delay in treatment and proper care. In patients with shortness of breath due to Heart Failure, increased plasma levels of NT-ProBNP can be demonstrated. The use of NT-ProBNP as a biomarker for heart failure in patients with acute dyspnoea might improve care and reduce the length of hospital stay.(5) This study was designed to assess plasma NT-ProBNP level in differentiating dyspnoea from cardiac and non-cardiac causes.

\section{MATERIALS AND METHODS}

84 patients admitted with Acute Dyspnoea of varying aetiology were selected for such study. The inclusion criteria were age $>15$ years and acute dyspnoea as their most prominent symptoms. Dyspnoea due to chest trauma, renal insufficiency (serum creatinine $>2.5 \mathrm{mg} / \mathrm{dL}$ ), previously known as valvular heart diseases and severe coronary ischaemia identified as $>0.1$ MV ST-segment elevation or ST-depression on 12-lead ECG were excluded from the study. After enrolment of history and clinical examination all routine blood chemistry, electrocardiography, Troponin-I, chest x-ray and spirometry were done, and the additional blood sample was collected for NT-ProBNP.

\section{NT-ProBNP Analysis}

NT-ProBNP concentration was measured by Enzyme-linked fluorescent assay (VIDAS Automated quantitative test). The analytic range was $20-25000 \mathrm{pg} / \mathrm{mL}$. The recommended decision threshold as per the Manufacturer's (Bio-Merieux, France) Literature were $125 \mathrm{pg} / \mathrm{mL}$ for patients $<75$ years old and $450 \mathrm{pg} / \mathrm{mL}$ for the patients $\geq 75$ years old.

\section{Principle}

The Enzyme-linked fluorescent assay (ELFA) principle is to combine a one-step immunoassay sandwich method with a final fluorescence detection.

The Solid Phase Receptacle (SPR) served as the solid phase as well as the pipetting device. Reagents for the assay were ready to use and pre-dispensed into a strip. All of the assay steps were performed automatically by the instrument. The sample was transferred into the well containing anti-NTProBNP antibody (conjugate) labelled with alkaline phosphatases. The sample/ conjugate mixture was cycled in and out of the SPR several times. This operation enabled the antigen to bind with the immunoglobulin fixed to the interior wall of SPR and to the conjugate to form a sandwich. Unbound compounds were eliminated during washing step.

The substrate (4-Methylumbelliferyl phosphates) was cycled in and out of the SPR. The conjugate Enzyme-catalysed the hydrolysis of this substrate into a fluorescent product (4Methylumbelliferone), the fluorescence of which measured at $450 \mathrm{~nm}$. The intensity of the fluorescence was proportional to the concentration of antigen present in a sample.
At the end of the assay, the results were automatically calculated by the instrument in a relation of two calibration curves corresponding to the two detection steps. A fluorescence threshold value determined the calibration curve to be used for each sample. The results were then printed out.

\section{Statistical Analysis}

All results for continuous variables were expressed as means \pm SD (standard deviation). However, since the distribution of NT-ProBNP was skewed, therefore median values with IQR were also considered. This is a cross-sectional study designed to know the plasma NT-ProBNP relation with the different types of acute dyspnoea, left ventricular ejection fraction, death and survival. The Mann-Whitney test were done for analysis of data between continuous variables. The analysis is done using ANOVA (Analysis of Variance) to evaluate the NTProBNP with different classes of NYHA severity. The difference between mean values were evaluated with unpaired T-test. To compare the patient's characteristics defined by the groups with low and high levels of NT-ProBNP, we used the Fisher's exact test. Diagnostic statistics used to compare specificity and sensitivity between two diagnostic tests has been illustrated through ROC (Receiver Operating Characteristic) curves. The NT-ProBNP detection using ROC platform makes testing accessible to health care persons. A ' $\mathrm{p}$ ' value $<0.05$ was considered statistically significant. Analysis of the data was done using a software SPSS system 16.0. Microsoft word and excel had been used to generate graphs and tables.

\section{RESULTS}

84 patients were included in the study, out of which 55 $(65.4 \%)$ were male and $29(34.6 \%)$ were females. The age of the patients studied was above 15 years with $24(28.57 \%)$ cases in the age group 56 - 65 years, $16(19.04 \%)$ were in 15 25 years and $3(3.57 \%)$ cases were above 76 years. Total cases were categorised into cardiac and non-cardiac causes of acute dyspnoea. Out of that, cardiac dyspnoea was $47.6 \%$ and noncardiac dyspnoea was $52.3 \%$ in Table 1.

\begin{tabular}{|c|c|c|}
\hline Types & Male & Female \\
\hline $\begin{array}{c}\text { Group-A: Patients of dyspnoea of } \\
\text { Cardiac origin: 40 (47.6\%) }\end{array}$ & $\begin{array}{c}26 \\
(30.95 \%)\end{array}$ & $\begin{array}{c}14 \\
(16.67 \%)\end{array}$ \\
\hline $\begin{array}{c}\text { Group-B: Patients of dyspnoea of } \\
\text { Non-Cardiac origin: 44 (52.3\%) }\end{array}$ & $\begin{array}{c}29 \\
(65.9 \%)\end{array}$ & $\begin{array}{c}15 \\
(34.1 \%)\end{array}$ \\
\hline \multicolumn{2}{|c|}{ Table 1. Distribution of Cases between Groups of } \\
Cardiac and Non-Cardiac Causes of Dyspnoea
\end{tabular}

Among the cardiac diseases presenting acute dyspnoea, cardiomyopathy was having highest median plasma NTProBNP level of $7293.33 \mathrm{pg} / \mathrm{mL}$ (IQR-2578 pg/ mL) and lowest value for patient of thyrotoxicosis heart failure 566 $\mathrm{pg} / \mathrm{mL}(\mathrm{IQR}=0)$. Among all non-cardiac causes, acute severe asthma patients had highest median plasma. NT-ProBNP level was $158.0 \mathrm{pg} / \mathrm{mL}$ (IQR-152.0 pg/ mL) and was lowest for pneumothorax $57.0 \mathrm{pg} / \mathrm{mL}(\mathrm{IQR}=0)$.

This study revealed that the mean \pm SD plasma NT-ProBNP concentration among patients of cardiac causes of dyspnoea was $4539.7 \pm 4342.9 \mathrm{pg} / \mathrm{mL}$, which was significantly higher than the patients of non-cardiac conditions of dyspnoea where mean \pm SD NT-ProBNP was $136.6 \pm 94.7 \mathrm{pg} / \mathrm{mL}$. This difference was statistically significant $(\mathrm{P} \leq 0.00001)$. Table- 2 and Data-1 are showing these differences. 


\begin{tabular}{|c|c|c|c|c|c|c|c|c|}
\hline Groups & No. of Cases & Mean & p50 & IQR & SD & Value-U & Z-Score & Probability \\
\hline A & $40(47.6 \%)$ & 4539.7 & 4300.0 & 4460.0 & 4342.9 & 2 & -7.85908 & P $<0.00001$ \\
\hline B & $44(52.4 \%)$ & 136.6 & 112.5 & 92.5 & 94.7 & & $(\mathrm{~S})$ \\
\hline \multicolumn{10}{|c|}{ S-Significant } \\
\hline \multicolumn{10}{|c|}{ Table 2. Comparison between Plasma NT-ProBNP Value in Patients of Cardiac (Group A) and Non-Cardiac } \\
(Group B) causes of Acute Dyspnoea
\end{tabular}

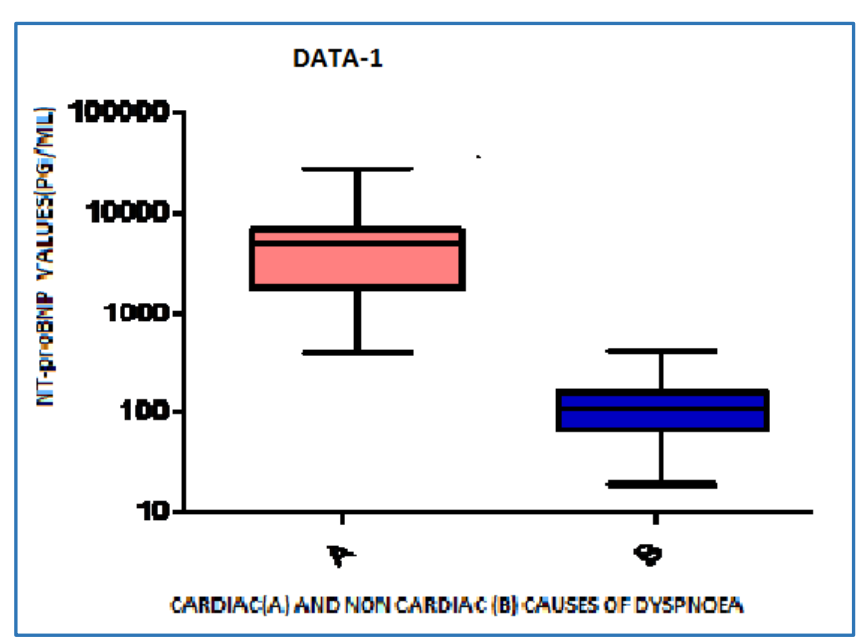

On analysis using ANOVA (Analysis of Variance) of different symptom severity based on New York Heart Association (NYHA) Classification I - IV of dyspnoea with mean \pm SD, NT-ProBNP levels had evaluated.

The ANOVA of mean \pm SD NT-ProBNP values with NYHA-I Class were $136.6 \pm 94.7411 \mathrm{pg} / \mathrm{mL}$, NYHA-II $1058.66 \pm$ $165.9076 \mathrm{pg} / \mathrm{mL}$, NYHA-III $2754.40 \pm 2143.5586 \mathrm{pg} / \mathrm{mL}$ and NYHA-IV $5587.7 \pm 4788.9649 \mathrm{pg} / \mathrm{mL}$, which were statistically significant $(\mathrm{P}<0.00001)$. This finding suggests plasma mean \pm SD NT-ProBNP value had the definite relationship with NYHA symptoms severity of the cardiac diseases. The results show this difference in Table 3.

\begin{tabular}{|c|c|c|c|c|}
\hline & $\begin{array}{l}\text { No. of } \\
\text { Cases }\end{array}$ & Mean \pm SD & F-Ratio & P-Values \\
\hline NYHA-I & 44 & $\begin{array}{l}3136.6 \pm \\
94.7411\end{array}$ & \multirow{4}{*}{21.06702} & \multirow{4}{*}{$<0.00001(\mathrm{~S})$} \\
\hline NYHA-II & 3 & $\begin{array}{l}1058.66 \pm \\
165.9076 \\
\end{array}$ & & \\
\hline NYHA-III & 10 & $\begin{array}{c}2754.40 \pm \\
2143.5586 \\
\end{array}$ & & \\
\hline NYHA-IV & 27 & $\begin{array}{c}5587.7 \pm \\
4788.9649 \\
\end{array}$ & & \\
\hline \multicolumn{5}{|c|}{ S-Significant } \\
\hline \multicolumn{5}{|c|}{$\begin{array}{c}\text { Table 3. ANOVA of Plasma NT-proBNP Values in Patients of } \\
\text { Cardiac causes of Dyspnoea according to NYHA (New York } \\
\text { Heart Association Classification of Dyspnoea) }\end{array}$} \\
\hline
\end{tabular}

Median NT-ProBNP values of patients were having LVEF $<50 \%$ in left ventricular systolic dysfunction was $4580 \mathrm{pg} / \mathrm{mL}$ (IQR- $3180 \mathrm{pg} / \mathrm{mL}$ ) and LVEF > 50\% in left ventricular diastolic dysfunction was $150 \mathrm{pg} / \mathrm{mL}$ (IQR- $713 \mathrm{pg} / \mathrm{mL}$ ) of both cardiac and non-cardiac acute dyspnoea correlation was statistically significant $\mathrm{P}<0.00001$. Table 4 is showing these levels.

\begin{tabular}{|c|c|c|c|c|c|c|}
\hline 岳 & 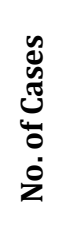 & 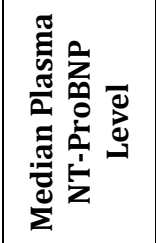 & 䒕 & 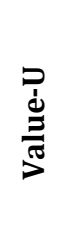 & 总 & 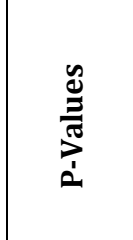 \\
\hline $\begin{array}{l}\text { LVEF } \\
\geq 50 \%\end{array}$ & 63 & $150 \mathrm{pg} / \mathrm{mL}$ & $713 \mathrm{pg} / \mathrm{mL}$ & \multirow{2}{*}{135} & \multirow{2}{*}{$\begin{array}{c}- \\
5.43359\end{array}$} & \multirow{2}{*}{$\begin{array}{c}<0.00001 \\
(S)\end{array}$} \\
\hline $\begin{array}{l}\text { LVEF } \\
<50 \%\end{array}$ & 21 & $\begin{array}{c}4580 \\
\mathrm{pg} / \mathrm{mL}\end{array}$ & $\begin{array}{c}3180 \\
\mathrm{pg} / \mathrm{mL}\end{array}$ & & & \\
\hline \multicolumn{7}{|c|}{ S-Significant } \\
\hline \multicolumn{7}{|c|}{$\begin{array}{c}\text { Table 4. Correlation between Median Plasma NT-ProBNP } \\
\text { Values with Left Ventricular Ejection Fraction ( } \geq \text { and }<\text { ) in } \\
\text { Patients of Cardiac and Non-Cardiac causes of Acute } \\
\text { Dyspnoea }\end{array}$} \\
\hline
\end{tabular}

Receiver operating characteristic (ROC) curve for NTProBNP had shown plasma NT-ProBNP values of 425.00 $\mathrm{pg} / \mathrm{mL}$ was the sensitivity of $97.5 \%$ and specificity of $97.7 \%$, which was superior to other value in distinguishing cardiac and non-cardiac causes of acute dyspnoea. This is shown in Graph-1.

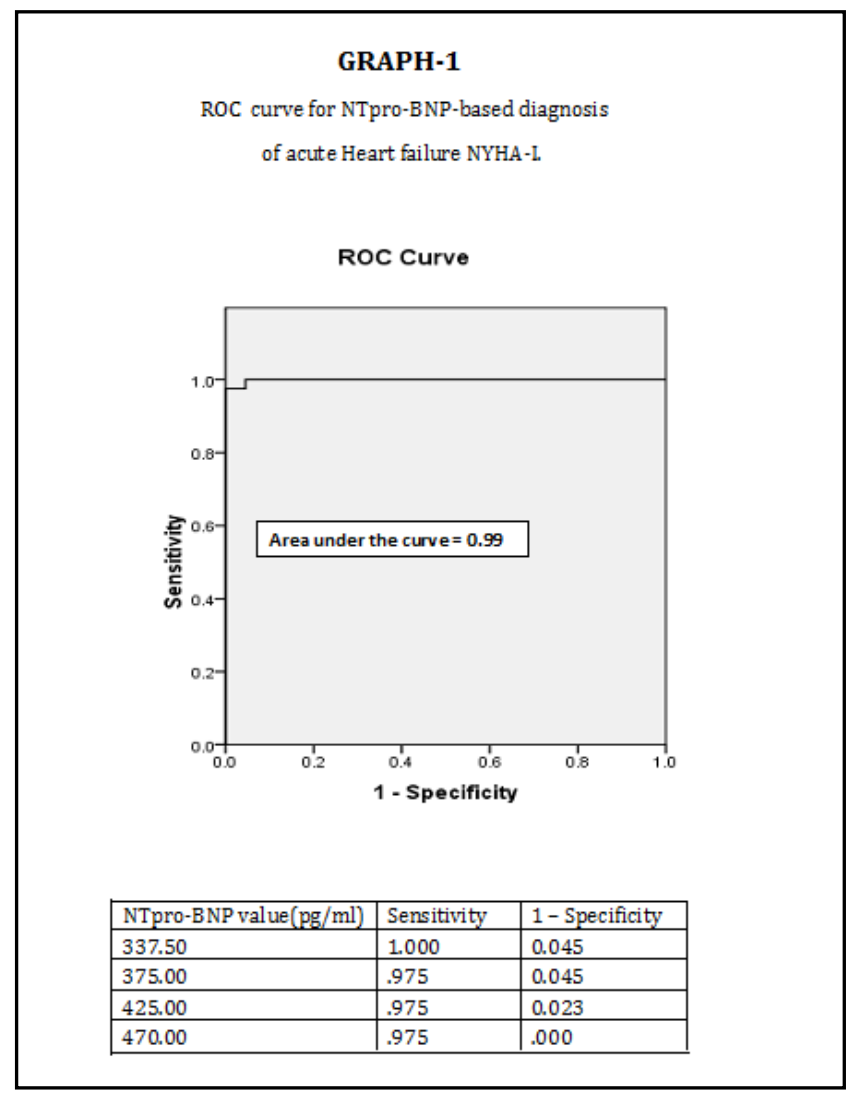

ROC curve was showing the plasma NT-ProBNP values of $888 \mathrm{pg} / \mathrm{mL}$ with the sensitivity of $66.7 \%$ and specificity of $59.3 \%$ for NYHA-II and for NYHA-III, it was $507.50 \mathrm{pg} / \mathrm{mL}$ with $90 \%$ sensitivity and $61.8 \%$ specificity. This is shown in Graph 2. 


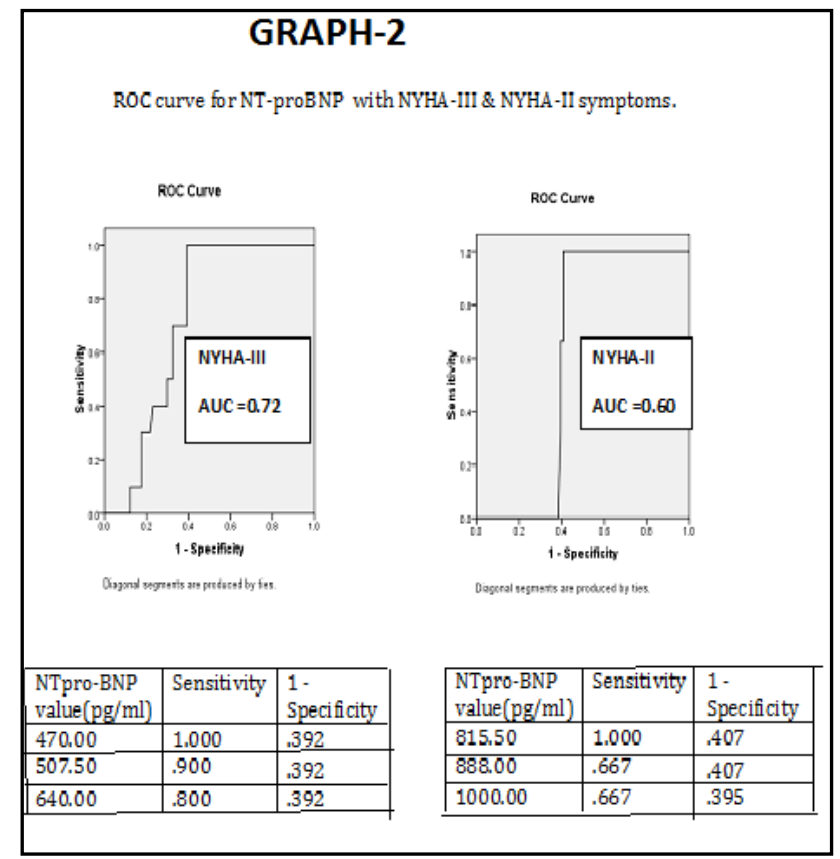

ROC curve had shown NT-PROBNP values of $375.00 \mathrm{pg} /$ $\mathrm{mL}$ with the sensitivity of $96.3 \%$ and specificity of $83.7 \%$ in NYHA-IV symptoms. This was revealed that plasma NTProBNP values were more specific and sensitive in determining the severity of dyspnoea grades. This is shown in Graph 3.

\section{GRAPH-3}

ROC curve for NTpro-BNP with NYHA-IV symptoms

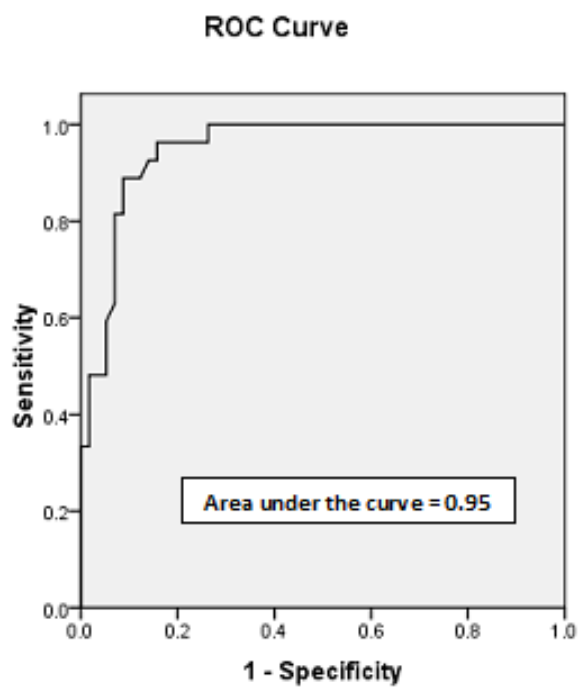

Diagonal segments are produced by ties

\begin{tabular}{|c|c|c|}
\hline $\begin{array}{c}\text { NTpro-BNP } \\
\text { value(pg/ml) }\end{array}$ & Sensitivity & 1 - Specificity \\
\hline 337.50 & 1.000 & 0.263 \\
\hline 375.00 & 0.963 & 0.263 \\
\hline 425.00 & 0.963 & 0.246 \\
\hline
\end{tabular}

ROC curve comparison of NT-ProBNP versus clinical judgment for diagnosis of cardiac dyspnoea showed that NTproBNP testing was superior to those of clinical judgment with a significantly greater area under the curve $(0.94$ vs. 0.91 , $\mathrm{P}=0.008)$. This is shown in Graph 4.

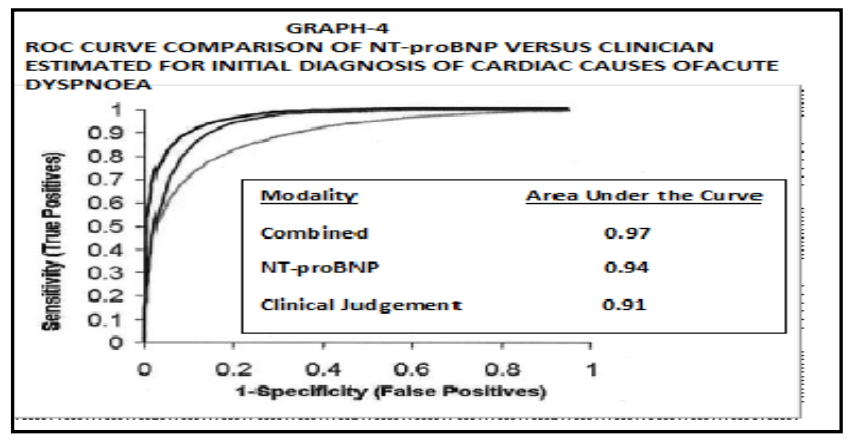

Out of 84 cases 6 patients (7.1\%) died during their stay in the hospital, 4 cases because of heart failure and 2 due to the non-cardiac cause. Among those who were dead, their median plasma NT-ProBNP level was $4420 \mathrm{pg} / \mathrm{mL}$ (IQR-7810) compared to $317.5 \mathrm{pg} / \mathrm{mL}$ (IQR-2894) from those who survived $(\mathrm{P}<0.15)$. The results are shown in Table 5.

\begin{tabular}{|c|c|c|c|c|c|c|}
\hline Outcome & $\begin{array}{c}\text { No. of } \\
\text { Cases }\end{array}$ & $\begin{array}{c}\text { Median } \\
\text { NroBN- } \\
\text { value } \\
\text { (pg/mL) } \\
\text { with }\end{array}$ & IQR & $\begin{array}{c}\text { Value- } \\
\text { U }\end{array}$ & $\begin{array}{c}\text { Z- } \\
\text { Score }\end{array}$ & Probability \\
\hline $\begin{array}{c}\text { Death (In- } \\
\text { Hospital) }\end{array}$ & 6 & 4420 & 7810 & 151.5 & $\begin{array}{c}- \\
\text { p= } 0.15 \\
\text { (NS) }\end{array}$ \\
\hline Discharged & 78 & 317.5 & 2894 & 1.4242 & NS- Non-Significant \\
\hline \multicolumn{7}{|c|}{}
\end{tabular}

Table 5. Comparison between Median Plasma NT-ProBNP Values between Patients of In-Hospital Death and Survivor

\section{DISCUSSION}

In the present study, out of 84 cases $64.5 \%$ were male and $34.6 \%$ were female and the majority of cases belonged to the age group of 56 - 65 years. The study by Januzzi et al in PRIDE study and by Domingo A et al was consistent with our study.(3,6) Total cases were categorised into cardiac and noncardiac causes of acute dyspnoea. Cardiac dyspnoea were 47.6\% and non-cardiac dyspnoea were $52.3 \%$ from Table 1. Study of Januzzi et al in PRIDE study, Domingo A et al, Zhu Y et al and Berdague $\mathrm{P}$ et al also had categorised the cases in a similar way. $(3,6,7,8)$ In our study, among the cardiac diseases presenting with acute dyspnoea of cardiomyopathy were having highest median plasma NT-ProBNP level of 7293.33 $\mathrm{pg} / \mathrm{mL}$ (IQR- $2578 \mathrm{pg} / \mathrm{mL}$ ) and lowest value for patients of thyrotoxicosis heart failure of $566 \mathrm{pg} / \mathrm{mL}(\mathrm{IQR}=0)$. Among all non-cardiac causes acute severe asthma patient's plasma NTProBNP level was highest, i.e. level of 158.0 pg/ mL (IQR-152.0 $\mathrm{pg} / \mathrm{mL}$ ) and lowest for pneumothorax of $57.0 \mathrm{pg} / \mathrm{mL}(\mathrm{IQR}=0)$. Similar results were seen by Zanuzzi et al.(3)

In this study, mean \pm SD plasma NT-ProBNP values in cardiac dyspnoea patients were $4539.7 \pm 4342.9 \mathrm{pg} / \mathrm{mL}$ and $136.6 \pm 94.7 \mathrm{pg} / \mathrm{mL}$ in non-cardiac dyspnoea patients. This difference is statistically significant $(P$ value $\leq 0.00001)$. Earlier studies by Januzzi et al in PRIDE study, Berdague $P$ et al, Moe et al, Zhu Y et al and Januzzi et al in ICON study had shown high plasma NT-ProBNP in cardiac dyspnoea and low 
in non-cardiac dyspnoea patients $(3,7,8,9,10)$ as presented from Table 2 and Data 1. On analysis using ANOVA (Analysis of Variance) of mean \pm SD NT-ProBNP levels with the symptom severity based on NYHA Classification I - IV values with NYHAI Class was $136.6 \pm 94.7411 \mathrm{pg} / \mathrm{mL}$, NYHA-II - $1058.66 \pm$ $165.9076 \mathrm{pg} / \mathrm{mL}$, NYHA-III $-2754.4 \pm 2143.5586 \mathrm{pg} / \mathrm{mL}$, NYHA-IV- $5587 \pm 4788.9649 \mathrm{pg} / \mathrm{mL}$ had evaluated and P value $<0.00001$, which were statistically significant. This finding suggests plasma mean \pm SD NT-ProBNP value had the definite relationship with NYHA symptom severity of the cardiac diseases. The results show this difference in Table 3. Similar results were established by Januzzi et al in PRIDE study and ICON study. $(3,10)$

In our study, among the cardiac dyspnoea 21 cases were left ventricular systolic dysfunction $<50 \%$ (LVEF < 50\%) and 63 cases were having left ventricular diastolic dysfunction $\geq 50 \%$ (LVEF $\geq 50 \%$ ). The median NT-ProBNP values of patients were having LVEF $<50 \%$ in Left ventricular systolic dysfunction of $4580 \mathrm{pg} / \mathrm{mL}$ (IQR- $3180 \mathrm{pg} / \mathrm{mL}$ ) and LVEF $\geq 50 \%$ in Left ventricular diastolic dysfunction of $150 \mathrm{pg} / \mathrm{mL}$ (IQR- $713 \mathrm{pg} / \mathrm{mL}$ ) and the correlation was statistically significant $P<0.00001$. Table 4 is showing these values. This finding was consistent with an earlier study by O'Donoghue et al.(11)

Receiver operating characteristic (ROC) curve for NTProBNP was showing plasma NT-ProBNP values of 425.00 $\mathrm{pg} / \mathrm{mL}$ were the sensitivity of $97.7 \%$ and specificity of $97.5 \%$, which was superior to other values in distinguishing between cardiac and non-cardiac causes of acute dyspnoea. This result was consistent with an earlier study by Januzzi et al.(3) The ProBNP investigation of dyspnoea in the emergency department (PRIDE study) was showing plasma NT-ProBNP level $<300 \mathrm{pg} / \mathrm{mL}$ was optimal to rule out acute Heart failure. Domingo A et al, Bayes-Genis A et al, Hobbs FD et al and Wright et al studies were showing high cut-off values of plasma NTProBNP > $900 \mathrm{pg} / \mathrm{mL} .{ }^{(12)}$ This was explained that these studies were undertaken among the elderly age groups (Mean age $\pm \mathrm{SD}=74 \pm 11$ yrs.) as compared to our study (Mean age \pm $\mathrm{SD}=46 \pm 30 \mathrm{yrs}.)^{(6,12,13,14)}$ from Graph-1.

ROC curve was showing the plasma NT-ProBNP values of $888 \mathrm{pg} / \mathrm{mL}$ with the sensitivity of $66.7 \%$ and specificity of $59.3 \%$ for NYHA-II and for NYHA-III, it was $507.50 \mathrm{pg} / \mathrm{mL}$ with $90 \%$ sensitivity and $61.8 \%$ specificity. ROC curve had shown NT-ProBNP values of $375.00 \mathrm{pg} / \mathrm{mL}$ with the sensitivity of $96.3 \%$ and specificity of $83.7 \%$ in NYHA-IV symptoms. This revealed that plasma NT-ProBNP values were more specific and sensitive in determining the severity of Dyspnoea grades. These results were consistent with earlier studies by Januzzi et al and Wang LL et al $(3,15)$ from Graph 2 and Graph 3.

ROC curve comparison of NT-ProBNP versus clinician estimated likelihood of initial diagnosis of cardiac causes of dyspnoea had shown results of NT-ProBNP testing which was superior to those of clinical judgement with a significantly greater area under the curve $(0.94$ vs. $0.91, \mathrm{P}=0.008)$. The area under the curve from NT-ProBNP testing plus clinical judgement were superior to each diagnostic modality from Graph 4. A similar observation had shown in PRIDE study of Januzzi et al.(3) In this study those patients died in hospital, their median plasma NT-ProBNP level was 4420 pg/ mL (IQR7810 ) as compared to $317.5 \mathrm{pg} / \mathrm{mL}$ (IQR-2894) of those who survived. The difference between median NT-ProBNP values was not statistically significant $(\mathrm{P}<0.15)$ in Table 5 . However, in ICON study (Januzzi et al 2006), Harrison et al and Doust et al 2005 observed high NT-ProBNP levels had the worse prognosis of patients. $(10,16,17)$ This discordance may be due to our small samples and follow-up for a short duration.

\section{CONCLUSION}

This study shows that a single measurement of NT-ProBNP on admission can provide independent diagnostic values for differentiating cardiac from non-cardiac causes of acute dyspnoea. High levels of plasma NT-ProBNP values are more specific and sensitive in determining the severity of dyspnoea and also are associated with a significant rise in mortality risk. It represents a useful biochemical tool for the rapid and reliable recognition of cardiac involvement in patients who are presenting with acute dyspnoea. Plasma NT-ProBNP can facilitate the diagnosis and also guide therapy as its highest values are directly related to more advanced NYHA classes and to the poor prognosis. The utility of plasma NT-ProBNP level can reduce the time to start the most appropriate therapy, reduces the need for hospitalisation and intensive care management. Further research on this biomarker would be likely to identify various stages during the evaluation of heart failure ranging from their use for screening, diagnosis, determining prognosis and guiding management.

\section{REFERENCES}

[1] Ker JA. Use of NT-proBNP in clinical practice. SA Fam Pract 2004;46(10):50.

[2] Hess OM, Carroll JD. Clinical assessment of heart failure. In: Libby P, Bonow RO, Mann DL. eds. Braunwald's heart disease: a textbook of cardiovascular medicine. $8^{\text {th }}$ edn. Philadelphia: Elsevier Saunders 2008;23:56181.

[3] Januzzi JL, Camargo CA, Anwaruddin S, et al. The Nterminal pro-BNP investigations of dyspnoea in an emergency department. (PRIDE) study. Am J Cardiol 2005;95(8):948-54.

[4] Alibay Y, Beauchet A, El Mahmoud R, et al. Plasma NTerminal Natriuretic peptide and brain Natriuretic peptide in assessment of acute dyspnoea. Biomedicine and Pharmacotherapy 2005;59(1-2):20-4.

[5] Rutten JH, Steyerberg EW, Boomsma F, et al. NTerminal pro-BNP Natriuretic peptide testing in the emergency department: beneficial effects of hospitalization, costs and outcome. Am Heart J 2008;156(1):71-7.

[6] Pasual-Figal DA, Manzano-Fernandez S, Boronat M, et al. Soluble ST2, high-sensitivity troponin T-and Nterminal pro-B-type Natriuretic peptide: the complementary role for risk stratification in acutely decompensated heart failure. European Journal of Heart Failure 2011;13(7):718-25.

[7] Zhu Y, Cai B, Wang LL. The Diagnostic value of NTerminal pro-BNP in patients with dyspnoea. Sichuan Da Xue Xue Bao Yi Xue Ban 2008;39(3):458-60.

[8] Barbeque P, Caffin PY, Barazer I, et al. Use of N-terminal prohormone BNP: assay for etiological diagnosis of acute dyspnoea in elderly patients. Am Heart J 2006;151(3):690-8. 
[9] Moe GW, Howlett J, Januzzi JL, et al. N-terminal pro-Btype Natriuretic peptide testing improves the management of patients with suspected acute heart failure: primary results of the Canadian prospective randomized multicenter IMPROVE-CHF study. Circulation 2007;115(24):3103-10.

[10] Januzzi JL, van Kimmenade R, Lainchbury J, et al. NTproBNP testing for diagnosis and short-term prognosis in acute established heart failure: an international pooled analysis of 1256 patients: the International Collaboration of NT-proBNP Study. Eur Heart J 2006;27(3):330-7.

[11] O'Donoghue M, Chen A, Baggish AL, et al. The effects of ejection fraction on N-terminal ProBNP and BNP levels in patients with acute CHF: analysis from the ProBNP Investigation of Dyspnea in the Emergency Department (PRIDE) Study. J Card Fail 2005;11(5 Suppl):S9-S14.

[12] Bayes-Genis A, Santalo-Bel M, Zapico-Muniz E, etal. NTProBNP in the emergency diagnosis and in-hospital monitoring of patients with dyspnoea and ventricular dysfunction. Eur J Heart Failure 2004;6(3):301-8.
[13] Hobbs FD, Davis RC, Roalfe AK, et al. Reliability of Nterminal pro-brain Natriuretic peptide assay in the diagnosis of heart failure: cohort study of representative and high-risk community populations. BMJ 2002;324(7352):1498.

[14] Wright SP, Doughty RN, Pearl A, et al. Plasma aminoterminal pro-brain Natriuretic peptide and accuracy of heart failure diagnosis in primary care: a randomized, controlled trial. J Am Coll Cardiol 2003;42(10):1793800.

[15] Wang X, Li F, Gerdes AM. Chronic pressure overload cardiac hypertrophy and failure in guinea pigs: I. Regional hemodynamics and myocyte remodelling. J Mol Cell Cardiol 1999;31(2):307-17.

[16] Harrison A, Monison LK, Krishnaswamy P, et al. B-type Natriuretic peptide predicts future cardiac events in patients presenting to the emergency department with dyspnoea. Ann Emerg Med 2002;39(2):131-8.

[17] Doust JA, Pietrzak E, Dobson A, et al. How well does Btype natriuretic peptide predicts death and cardiac events in patients with heart failure: systemic review. BMJ 2005;330(7492):625. 